BAKTIMAS

Jurnal Pengabdian pada Masyarakat
Vol. 1, No. 4,

Desember 2019
eISSN 2685-113x

pISSN 2685-0303

\title{
Diversifikasi Produk Olahan Kelapa Bagian Dalam bagi Enterpreneurship Bumdes Di Jambi
}

\author{
Musnaini $^{1}$, Rike Setiawati ${ }^{2}$, Besse Widiawati ${ }^{3}$ \\ ${ }^{1,2,3}$ Universitas Jambi \\ Universitas Jambi, Jl. Raya Jambi - Muara Bulian KM.15 Mendalo Indah Muaro Jambi, \\ Jambi, Indonesia, 0741-583377 \\ e-mail: ${ }^{* 1}$ musnaini@unja.ac.id; ${ }^{2}$ Rike_setiawati@unja.ac.id; \\ 33idya_anwary@yahoo.com \\ Penulis Koresponden: musnaini@unja.ac.id \\ DOI : 10.32672/btm.v1i4.1719
}

\begin{abstract}
ABSTRAK
Pelatihan peningkatan diversifikasi produk Olahan Kelapa Bagian Dalam yang berkualitas. Kegiatan pengabdian ini ditujukan untuk mengatasi persoalan yang mengemuka yaitu masalah manajemen produksi olahan kelapa bagian dalam khususnya pengolahan Virgin Coconut Oil (VCO) dan manajemen pemasarannya serta izin pemasaran (BPOM, P-IRT dan sertifikasi halal), manajemen pemasaran terkait strategi bersaing. Mitra pengabdian ini terdiri dari Bumdes Manunggal Jaya di Desa Manunggal Makmur Kecamatan Kualo Jambi dan Bumdesa Mart Desa Penyengat Olak Kecamatan Jambi Luar Kota. Pengabdian dilakukan selama 7 Bulan (Bulan April sampai dengan Oktober tahun 2019). Solusi yang ditawarkan adalah program pelatihan dan pendampingan menggunakan strategi fungsional berupa manajemen produksi, manajemen pemasaran, dan pendampingan pengurusan aspek legalitas produk olahan kelapa dalam khususnya VCO (labeling dan kemasan). Untuk keberlanjutan produksi olahan kelapa bagian dalam perlu diversifikasi produk berupa Virgin Coconut Oil (VCO), nata coco, dan cuka kelapa dan standarisasi kualitas produk. Selanjutnya pengembangan pemberdayaan produksi, manjemen pemasaran serta sumberdaya manusia untuk menjaga dan meningkatkan kualitas produk kelapa dalam membutuhkan dengan fasilitator aktif badan usaha milik desa dan peran kegiatan pengabdian masyarakat dari Universitas Jambi.

Kata kunci: VCO, Cuka Kelapa, Nata de coco, Manjemen Pemasaran, Bumdes
\end{abstract}

\section{PENDAHULUAN}

Selama ini hasil panen kelapa hybrida di kabupaten Tanjung Jabung Timur hanya di jual dalam bentuk kelapa bulat ataupun kopra. Salah satu desa penghasil kelapa di Kabupaten Tanjab Timur yaitu desa manunggal makmur. Akan tetapi nilai tambah yang diperoleh dari potensi lokal berupa kelapa tersebut belum menunjukkan signifikansi terhadap peningkatan kesejateraan masyarakat setempat. Karena selama ini produksi kelapa yang melimpah tidak dikelolah atau dikembangkan berupa produk turunan kelapa berupa minyak kelapa, vorgin coconut oil, santan cair, santan bubuk untuk daging kelapa, sementara untuk air kelapa dapat berupa nata de coco, Hydro coco, cuka, penggumpal lateks dan lain lain (Purwana, 2019). Hal ini dianggap belum 
BAKTIMAS

Jurnal Pengabdian pada Masyarakat
Vol. 1, No. 4,

Desember 2019
eISSN 2685-113x

pISSN 2685-0303

optimal meningkatkan penghasilan petani kelapa, karena sering kali saat harga kelapa jatuh di pasaran petani mengalami masa paceklik. Belajar dari fenomena tersebut terkait nilai tambah (value added) pada komoditi kelapa dapat meningkatkan pendapatan masyarakat (Palupi, Alamsyah, Nainggolan, 2017).

Untuk mengoptimalkan potensi lokal terkait kekayaan hasil perkebunan kelapa Kabupaten Tanjung Jabung Timur, Provinsi Jambi, melalui Bumdes Manunggal Jaya di Desa Manunggal Makmur di kecamatan Kuala Jambi, Kabupaten Tanjung Jabung Timur berupaya mendiversivikasi produk olahan kelapa bagian dalam berupa produk olahan kelapa bagian dalam berupa Virgin Coconut Oil, Nata de Coco dan Cuka Kelapa. Saat ini BUMDES Manunggal Jaya telah membina usaha rumah tangga dalam mengolah produk kelapa bagian dalam berupa nata de coco dan VCO. Namun seiring berjalannya waktu BUMDES mengalami kesulitan dalam hal manjemen produksi, seperti masalah standariasasi kualitas VCO, nata de coco dan cuka kalapa yang masih rendah (VCO tidak tahan lama dan bau tengik). Selain itu permasalahan dalam strategi bersaing terkait merek, kemasan, dan legaliasi yang belum terealisasi (seperti BPOM dan IRT).

Berdasarkan analisis situasi terhadap BUMDES Manunggal Jaya dalam pemberdayaan usaha rumah tangga untuk produk VCO, cuka kelapa dan Nata De coco maka pengabdian ini menawarkan solusi berupa inisiatif ide baru berupa diversifikasi produk kelapa bagian dalam yang berkualitas dan startegi pemasaran. Pengabdian kepada masyarakat yang dilaksanakan berfokus pada pelaku usaha produk olahan kelapa bagian dalam berupa VCO, cuka kelapa dan Nata De coco di desa Manunggal jaya sebagai target program dengan tujuan agar pelaku usaha rumah tangga mendapatkan pemahaman mengenai legalitas (merk dan standarisasi produk) dan manajemen pemasaran (kemasan) sehingga pemahaman tersebut dapat diterapkan dalam kegiatan usaha serta dapat memperbaiki kualitas produk yang sedang dijalankan. Salah satu tolok ukur berkembangnya usaha adalah adanya legalitas (merk) dan manajemen pemasaran (kualitas produk) sehingga dapat peningkatan omset pennjualan.

\section{METODE PELAKSANAAN}

Berdasarkan solusi yang ditawarkan dan disetujui oleh Mitra pengabdian baik mitra I dan mitra II maka secara garis besar kegiatan yang akan dilakukan pada kegiatan PPMPI ini adalah 1) Pelatihan manajemen Produksi; 2) Pelatihan Manajemen Pemasaran dan 3) Pendampingan usaha.

Untuk kegiatan pelatihan, metode yang akan diterapkan adalah metode pelatihan partisipatif yang melibatkan peserta pelatihan yang merupakan anggota mitra dalam setiap tahapan pelatihan mulai dari pra pelatihan hingga tahapan evaluasi pelatihan (Participant Learning Center/PLC). Terkait dengan pelatihan manajemen produksi dan pemasaran serta keuangan maka dihadirkan para ahli terkait bidangnya sebagai pelatih/instruktur, untuk manajemen produksi yitu pelatih ahli yang dihadirkan adalah Ahli pengolahan kelapa dalam, sementara untuk manajemen pemasaran maka pelatih yang dihadirkan adalah akademisi/praktisi pemasaran.

Secara rinci metode pelaksanaan masing-masing kegiatan disajikan pada bagan alur sebagai berikut: 
Musnaini, Rike Setiawati, Besse Widiawati

Tabel 1. Kegiatan, Tujuan, Metode serta bahan dan Alat

\begin{tabular}{|c|c|c|c|c|}
\hline No & Kegiatan & Tujuan Kegiatan & Metode & Bahan dan Alat \\
\hline \multirow[t]{2}{*}{1} & $\begin{array}{l}\text { Kontrak } \\
\text { Belajar }\end{array}$ & \begin{tabular}{llr} 
Membangun & \multicolumn{2}{c}{ kesepahaman } \\
mengenai tujuan dan \\
pelaksanaan PPMPI antara \\
Tim dan Mitra
\end{tabular} & $\begin{array}{l}\text { Ceramah, } \\
\text { diskusi }\end{array}$ & $\begin{array}{l}\text { White board, spidol, } \\
\text { Kertas Plano }\end{array}$ \\
\hline & $\begin{array}{l}\text { Pelatihan } \\
\text { Manajemen } \\
\text { Produksi } \\
\text { Olahan } \\
\text { kelapa dalam }\end{array}$ & $\begin{array}{l}\text { Melatih warga desa terpilih } \\
\text { untuk memproduksi VCO } \\
\text { yang berkualitas }\end{array}$ & $\begin{array}{l}\text { Praktek } \\
\text { membuat } \\
\text { VCO }\end{array}$ & $\begin{array}{ll}\text { - } & \text { Kelapa bulat } \\
\text { - } & \text { Pemarut kelapa } \\
\text { - } & \text { Pemeras santan } \\
\text { - } & \text { Tabung air } \\
\text { - } & \text { Bahan fermentasi } \\
\end{array}$ \\
\hline 2 & $\begin{array}{l}\text { Pelatihan } \\
\text { Manajemen } \\
\text { Pemasaran }\end{array}$ & 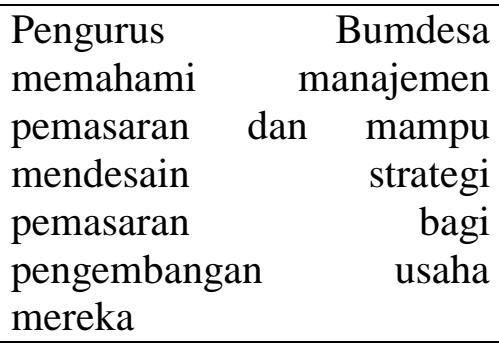 & $\begin{array}{l}\text { Ceramah, } \\
\text { Demonstrasi }\end{array}$ & $\begin{array}{l}\text { Daftar Hadir } \\
\text { Materi Manajemen } \\
\text { pemasaran }\end{array}$ \\
\hline 3 & $\begin{array}{l}\text { Pendampinga } \\
\mathrm{n} \quad \text { untuk } \\
\text { pengurusan } \\
\text { PIRT, dan } \\
\text { serifikasi } \\
\text { Halal } \\
\end{array}$ & $\begin{array}{l}\text { Menghasilkan izin PIRT } \\
\text { dan sertifikasi } \\
\text { produk } \\
\text { Manunggal Jaya }\end{array}$ & $\begin{array}{l}\text { Pendamping } \\
\text { an dan } \\
\text { fasilitasi ke } \\
\text { Instansi } \\
\text { terkait }\end{array}$ & Produk VCO \\
\hline 4 & \begin{tabular}{lr}
\multicolumn{2}{l}{ Diseminasi } \\
Ke media \\
cetak dan \\
Jurnal.
\end{tabular} & $\begin{array}{lr}\text { Menyebarluaskan } & \text { kegiatan } \\
\text { PPMPI } & \text { sekaligus } \\
\text { mempromosikan } & \text { produk } \\
\text { Bumdesa Mitra ke media } \\
\text { masa }\end{array}$ & $\begin{array}{l}1 \quad \text { artikel } \\
\text { jurnal } \\
1 \text { publikasi } \\
\text { kegiatan }\end{array}$ & $\begin{array}{l}\text { Artikel } \\
\text { Dokumentasi kegiatan }\end{array}$ \\
\hline
\end{tabular}

Tabel 2. Tahapan Kegiatan Program PKM

\begin{tabular}{|c|c|}
\hline \multicolumn{2}{|l|}{ Tahap persiapan } \\
\hline Pra-Survei & $\begin{array}{l}\text { Identifikasi permasalahan dan kebutuhan BUMdes } \\
\text { (permasalahan } \\
\text { spesifik yang dialami mitra) }\end{array}$ \\
\hline Pembentukan Tim PKM & $\begin{array}{l}\text { Pembentukan Tim disesuaikan dengan jenis } \\
\text { kepakaran untuk } \\
\text { menyelesaikan permasalahan BUMdes }\end{array}$ \\
\hline Pembuatan Proposal & $\begin{array}{l}\text { Pembuatan proposal untuk menawarkan solusi } \\
\text { permasalahan dan penyediaan dana dalam }\end{array}$ \\
\hline
\end{tabular}


BAKTIMAS

Jurnal Pengabdian pada Masyarakat
Vol. 1, No. 4,

Desember 2019
eISSN 2685-113x

pISSN 2685-0303

\begin{tabular}{|c|c|}
\hline & pelaksanaan solusi bagi BUMdes \\
\hline Koordiasi Tim \& Mitra & $\begin{array}{l}\text { Perencanaan pelaksanaan program secara } \\
\text { konseptual, operasional dan job describtion dari } \\
\text { Tim dan BUMdes }\end{array}$ \\
\hline $\begin{array}{l}\text { Persiapan Alat \&Bahan } \\
\text { Pelatihan }\end{array}$ & $\begin{array}{l}\text { Pembelian dan penyewaan alat serta pembuatan } \\
\text { materi kegiatan }\end{array}$ \\
\hline \multicolumn{2}{|c|}{ Tahap Pelaksanaan (Kegiatan Dilaksanakan di Lokasi BUMdes) } \\
\hline $\begin{array}{l}\text { Sosialisasi pengenalan merk dan } \\
\text { legalitas } \\
\text { meek dalam kegiatan usaha }\end{array}$ & $\begin{array}{l}\text { egiatan dilaksanakan melalui pemaparan materi } \\
\text { dan diskusi }\end{array}$ \\
\hline 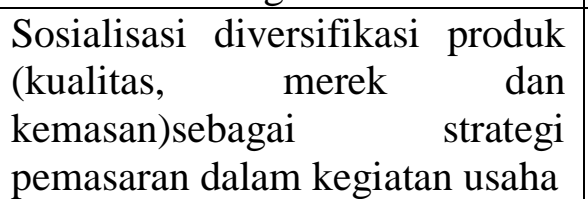 & $\begin{array}{l}\text { Kegiatan dilaksanakan melalui pemaparan materi } \\
\text { dan diskusi }\end{array}$ \\
\hline $\begin{array}{l}\text { Sosialisasi mekanisme strategi } \\
\text { pemasaran guna peningkatan } \\
\text { daya saing produk. }\end{array}$ & $\begin{array}{l}\text { Kegiatan dilaksanakan melalui pemaparan materi } \\
\text { dan diskusi }\end{array}$ \\
\hline \multicolumn{2}{|r|}{ Evaluasi Program } \\
\hline \multicolumn{2}{|c|}{$\begin{array}{l}\text { Dilakukan dengan membandingkan kondisi mitra sebelum dan sesudah pelaksanaan } \\
\text { program. } \\
\text { Indikator keberhasilan program dengan adanya perubahan positif dari mitra } \\
\text { (perkembangan usaha) setelah pelaksanaan program. }\end{array}$} \\
\hline \multicolumn{2}{|c|}{ Pelaporan } \\
\hline & \\
\hline
\end{tabular}

Program pengabdian kepada masyarakat dilaksanakan dalam bentuk sosialisasi kepada usaha ruamh tamgga pengolahan produk kelapa dalam pada Bumdes Manunggal Jaya di Desa Manunggal Makmur kecamatan Kuala Jambi, Kabupaten Tanjung Jabung Timur. pelatihan tersebut berupa pemaparan materi terkait permasalahan yang dihadapi yaitu aspek pentingnya merk, kualitas produk, dan aspek manajemen pemasaran.

Pengingkatan kualaitas produk, pengemasan dan pemberian merk merupakan hal yang sangat penting bagi badan usaha tertentu/ perusahaan. Karena kualtias produk dan merk dapat membedakan produk turuan kelapa dalam bagian dalam dengan yang lain. Materi yang akan disampaikan diharapkan dapat memberikan peningkatan pengetahuan dan pemahaman untuk selanjutnya dapat diterapkan oleh BUMDES dalam kegiatan usaha. Adapun materi yang akan disampaikan pada usaha rumah tangga meliputi : 
Musnaini, Rike Setiawati, Besse Widiawati

Tabel 3. Pelaksanaan Pelatihan diversifikasi produk turun kelapa bagian dalam kelapa

Pemateri

Dr. Rike Setiawati, SE, MM

Dr. Besse Widiawati, SE,MM

Dr.Musnaini,SE,MM

\begin{tabular}{|l|} 
Materi program \\
Pemantapam materi dan metode \\
Pengenalan produk di BUMDES \\
Manunggal Jaya
\end{tabular}

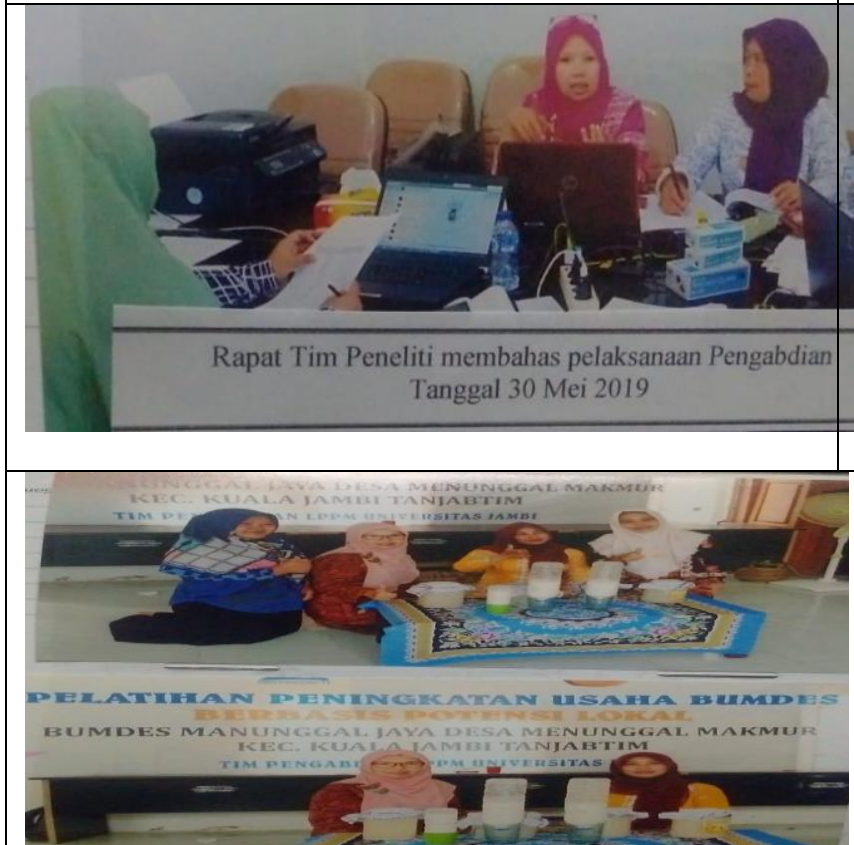

Pelatihan Proses Produksi oleh Bapak Dr. Mursalin, SP, MP

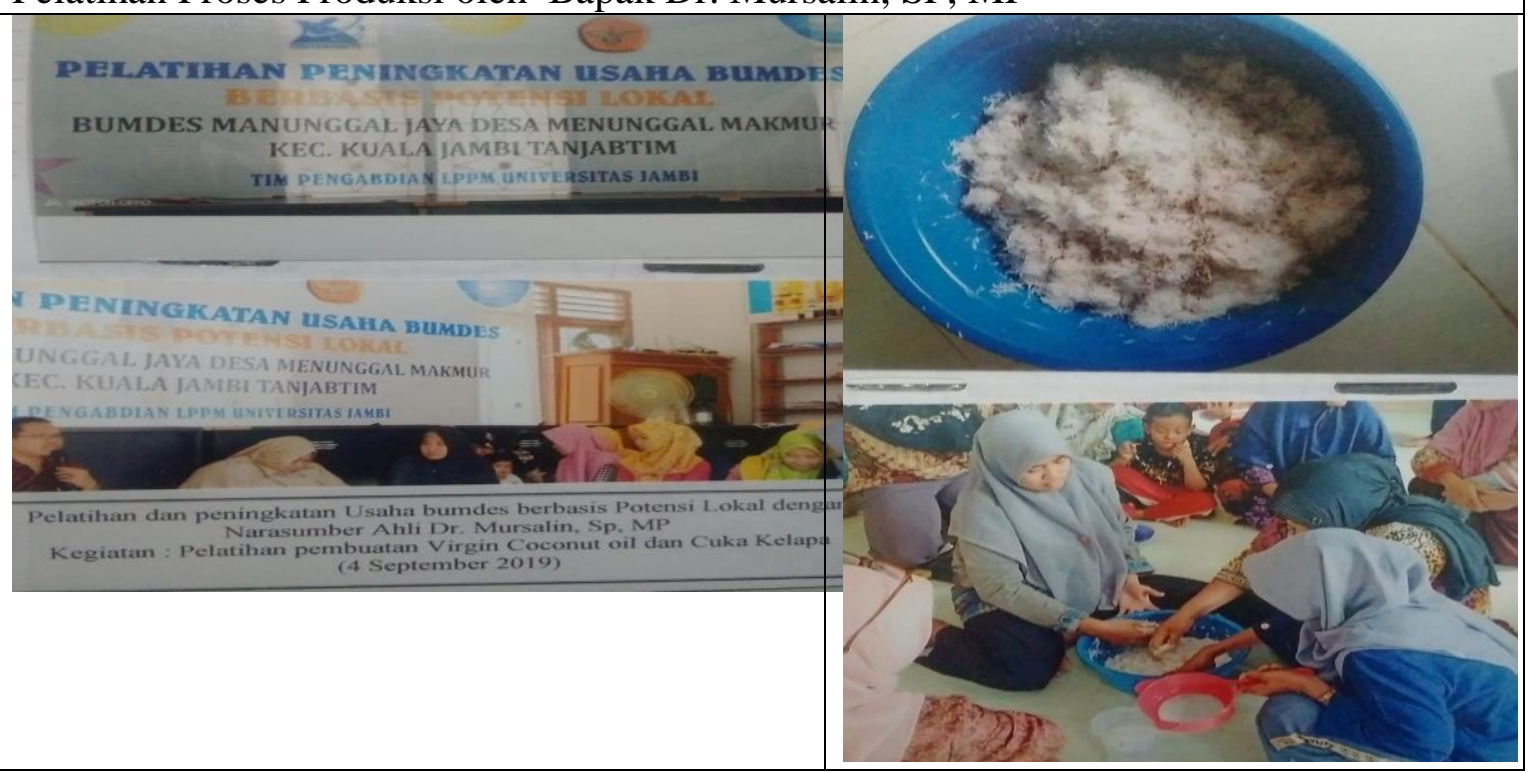


BAKTIMAS

Jurnal Pengabdian pada Masyarakat

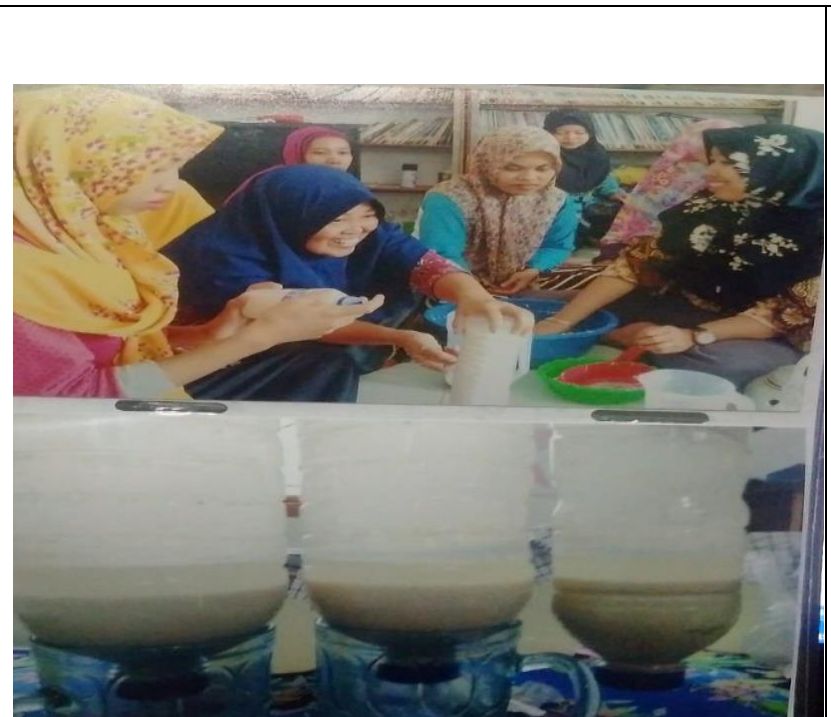

Proses produksi VCO

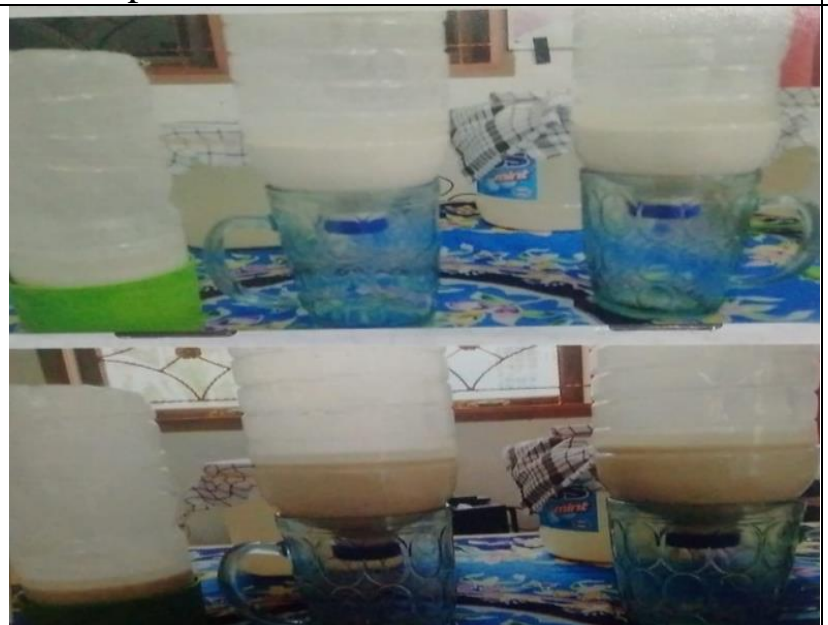

Hasil Pelatihan kemasan Cukai Kelapa

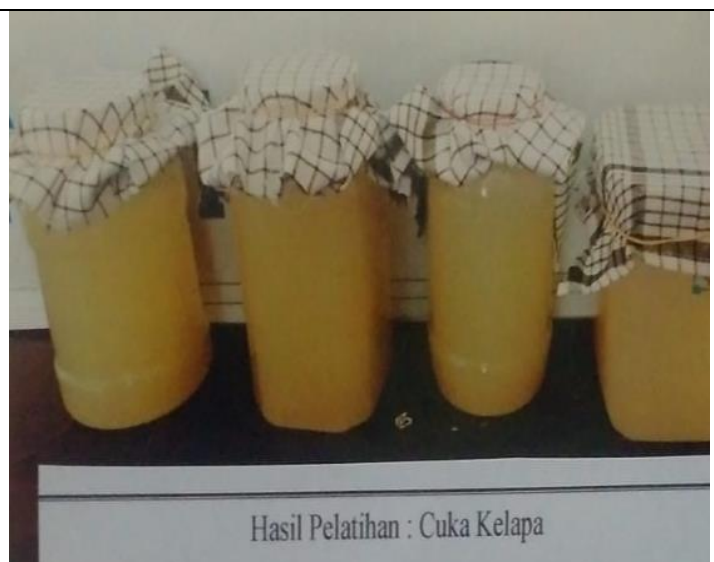

Vol. 1, No. 4,

Desember 2019
eISSN 2685-113x

pISSN 2685-0303

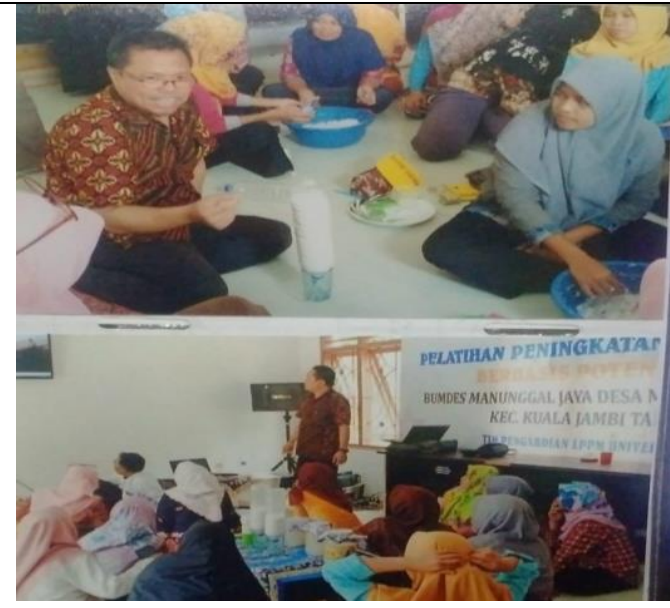

\section{Hasil pelatihan VCO}

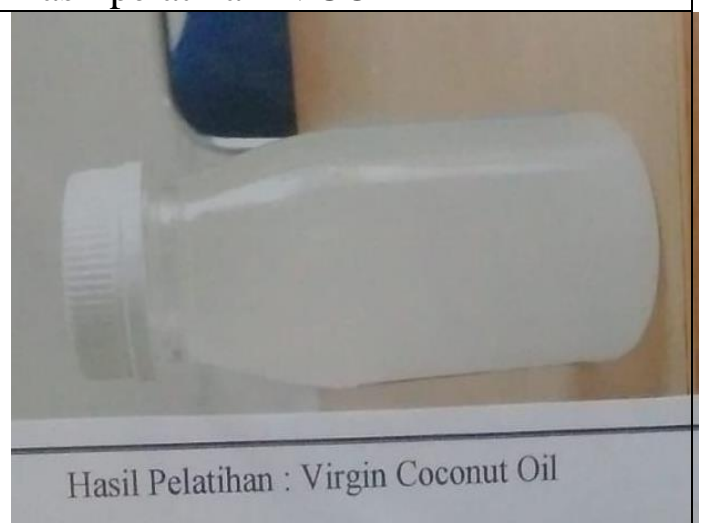

Hasil Pelatihan : Virgin Coconut Oil

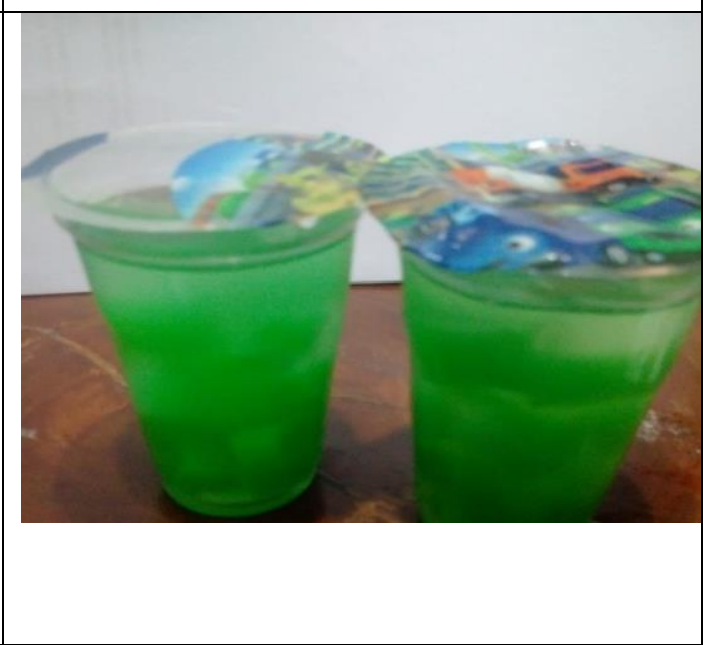


Musnaini, Rike Setiawati, Besse Widiawati

\section{HASIL DAN PEMBAHASAN}

Sebagaimana target capaian yang akan dihasilkan dari aktivitas pengabdian ini adalah meningkatkan keberdayaan mitra dalam hal pengolahan produk kelapa khususnya VCO, meningkatnya kemampuan pengurus Bumdes dalam merancang strategi pemasaran, membuat perencanaan kas, serta terbangunnya komitmen dan dukungan dari stakeholder untuk kemajuan Bumdes terkait.

Secara khusus target luaran dari kegiatan ini adalah bagi usaha rumahtangga produk olahan kelapa bagian dalam berupa : 1) produk VCO yang berkualitas dan tahan lama serta siap dipasarkan, 2) Ide produk turunan kelapa lainnya yang memiliki potensi pasar, 3) desain dan strategi pemasaran produk olahan kelapa dalam (nata de coco dan VCO), 4) izin PIRT dan Sertifikasi Halal.

Bagi Target yang telah ditetapkan tersebut maka sampai saat ini hasil yang telah dicapai berdasarkan tahapan kegiatannya adalah:

1. Pelatihan pembuatan VCO yang berkualitas dan varian produk turunan lainnya yaitu asam cuka kelapa.

2. Membantu mendesain strategi pemasaran produk olahan buah kelapa bagian dalam (nata de coco, asam cuka kelapa dan VCO) seperti pembuatan label produk, pendampingan izin PIRT dan Sertifikasi Halal.

\section{Simpulan}

\section{PENUTUP}

Kegiatan pengabdian telah dilaksanakan di dua lokasi tempat dimana mitra berada. Beberapa hal yang dapat disimpulkan dari hasil kegiatan Pengabdian Kepada Masyarakat :

1) Pengurus Bumdes dan Masyarakat Desa Manunggal Makmur sangat antusias mengikuti beberapa kegiatan pelatihan yang diadakan terkait dengan pelatihan produk olahan kelapa dalam berupa VCI, Cuka Kelapa dan Nata de Coco.

2) Warga Desa sepakat membentuk kelompok-kelompok usaha yang akan bertanggung jawab memproduksi VCO, Nata De Coco dan Cuka Kelapa terintegrasi dengan Bumdes.

\section{Saran}

Saran bagi Kegiatan Pengabdian Masyarakat ini yaitu dapat dilangsungkan di BUMDES di wilayah Kabupaten Tanjung Jabung Timur, Jambi. Selanjutnya dapat dilakukan pengabdian lebih lanjut dengan materi yang lebih luas lagi sehingga sangat bermanfaat bagi rumah tangga usaha pengolahan kelapa bagian dalam untuk mengembangkan usahanya.

Selain itu untuk sementara dari hasil kegiatan ini perlu keterlibatan pemerintah dlam hal ini Dinas Perindustrian dan Perdagangan dan Badan POM dan MUI terkait pengurusan izin PIRT dan Label Halal. Perlu keterlibatan pemerintah dalam hal ini Dinas Pemberdayaan Masyarakat Desa terkait peningkatan komitmen kepala Desa pembentuk Bumdes terutama dalam hal dukungan pendanaan. 
BAKTIMAS

Jurnal Pengabdian pada Masyarakat
Vol. 1, No. 4,

Desember 2019
eISSN 2685-113x

pISSN 2685-0303

\section{UCAPAN TERIMA KASIH}

Tim Pengabdian Kepada Masyarakat mengucapkan Terima Kasih Kepada Direktorat Riset dan Pengabdian Masyarakat-Ditjen Penguatan Riset dan pengembangan, Kemenristekdikti atas dukungan dana di pegabdian Masyarakat ini; Rektor Universitas Jambi yang telah mendorong kepada team pengabdian dan penelitian untuk mengembangkan diri dalam melaksanakan Tri Dharma Perguruan Tinggi. Dekan Fakultas Ekonomi dan Bisnis Uiversitas Jambi yang telah memberikn izin untuk melaksanakan Pengabdian. Bapak Kades Manunggal Makmur. Ketua dan Staf Lembaga Penelitian dan Pengabdian pada Masyarakat (LP2M) Universitas Jambi, dan seluruh team pengadian serta pengelola jurnal yang telah memberikan dukungan teknis dan administrasi dalam pengabadian ini hingga Penerbitan Artikel Ini.

\section{DAFTAR PUSTAKA}

Palupi, Alamsyah dan Nainggolan., 2017. Analisis Nilai Tambah Kelapa Dalam dan Pemasaran Kopra di Kecamatan Nipah Panjang Kabupaten Tanjung Jabung Timur, repository.unja.ac.id/4154/1/jurnal\%2017

Pupun Purwana (2016). Industri Pengolahan Kelapa Berbasis Desa Sebagai Penggerak Ekonomi Masyarakat Desa. http://bumdesindo.com/wp/industr-pengolahankelapa-berbasis-desa-penggerak-ekonomi-masyarakat-desa/ 